\title{
Parliamentary privilege in India
}

by D Shanmuganathan

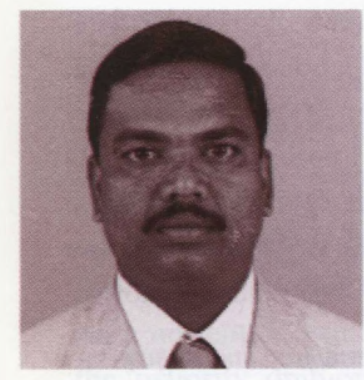

D Shanmuganathan

In this article the author offers some advice to the Indian Parliament in the light of the UK Joint Committee Report on Parliamentary Privilege 1999.

$\mathrm{O}$ n 1 May 2000, a full bench of the Supreme Court of India referred a case filed by the Centre for Public Interest Litigation to the Constitutional Bench requesting a 'declaration regarding the correctness' of the immunity provision under art. 105(2) of the Constitution for Members of Parliament without disturbing the judgment in the case of $P V$ Narasimha Rao v State (CBI/SPE) (1998) 4 SCC 626 (hereafter P V N Rao).

The Constitution provides immunity as follows:

'105. Powers, privileges etc. of the House of Parliament and of the Members and Committees thereof-

(1) $\ldots$

(2) No Member of Parliament shall be liable to any proceedings in any court in respect of anything said or any vote given by him in Parliament or any Committee thereof, and no person shall be liable in respect of the publication by or under the authority of either House of Parliament of any report, paper, votes or proceedings.'

On a previous occasion the Constitutional Bench of the Supreme Court, in a split decision of 3 to 2 , had held that Members of Parliament who accepted pecuniary advantages to vote in a particular pattern in the Parliament were entitled to immunity under art. 105(2) of the Constitution and absolved the charges levelled against them. In the present case, the petitioner's forum challenged that the lawmakers should not be granted 'absolute immunity' against prosecution. The petitioner's counsel told the Supreme Court that:

$\therefore$ when some of them give bribes to others to vote in

Parliament, in a particular manner, and if people with criminal backgrounds are put in those positions, they will have little or no respect for the rule of law. This will subvert the very basis of Parliamentary democracy.' (Times of India, 2 May 2000)

Furthermore the counsel informed the Supreme Court that:

'... the menace of corruption was posing a grave threat to parliamentary democracy, and every dignitary, right from the President and Prime Minister, had been expressing concern over this.'

The following day the Supreme Court's referral was echoed in the Parliament. Some members expressed their concern that the judiciary was intruding into the subject matter of parliamentary sovereignty and the result seemed likely to be a conflict between the legislature and the judiciary.

The following discussion of the Indian Supreme Court's earlier decision on parliamentary privilege and recent developments in relation to parliamentary privilege in the UK could be a guideline for the Indian Parliament. This would avoid the judiciary/legislature conflict, and provide a new law to prosecute Members of Parliament for bribery charges by amending the existing law in the Prevention of Corruption Act 1988.

\section{BACKGROUND}

Following the decision on 17 April 1998 in PVN Rao, where in a split decision of 3 to 2 the Constitutional Bench of the Supreme Court held that Members of Parliament accepting pecuniary advantages to vote in a no-confidence motion were entitled to immunity (see above), the Constitutional Bench considered a number of judgments addressing the issue of parliamentary privilege 
from various national courts in the UK, US, Australia and Canada, and failed to reach a unanimous decision. Although the Supreme Court of India discussed a judgment of Buckley $\mathrm{J}$ in which the Honourable Judge invoked the common law for corruption charges against a Member of Parliament in England, the Bench felt that as the judgment came from only a trial judge it could not be relied on as precedent ( $R_{V}$ Greenway \& Ors (1998) PL 356).

Moreover, the majority opinion identified that a sanctioning process, as required under the Prevention of Corruption Act 1988 for prosecuting public servants, is absent in relation to Members of Parliament, who are in essence also public servants. Section 19 of the Prevention of Corruption Act 1988 requires:

'Previous sanction necessary for prosecution -(1) No Court shall take cognisance of an offence punishable under s. 7, 10, 11,13 and 15 alleged to have been committed by a public servant, except with the previous sanction.'

Hence the Supreme Court left the issue of bribery related to Members of Parliament to be addressed by the Indian Parliament.

\section{SUPREME COURT REFERRAL}

On 1 May 2000, a full bench of the Supreme Court of India referred a case filed by the Centre for Public Interest Litigation to the Constitutional Bench requesting a 'declaration regarding the correctness' of the immunity provision under art. 105(2) of the Constitution for Members of Parliament...

The recent UK Joint Committee Report on Parliamentary Privilege 1999, headed by Lord Nicholls of Birkenhead (vol. 1, Stationery Office: London) addressed the issue of parliamentary privilege for bribery charges. It recommended that parliamentary privilege should be set aside for bribery charges against Members of Parliament and that the senior law officer of the State should be appointed as the competent authority to grant sanction to prosecute Members of Parliament. This recommendation could be helpful in addressing the issue of bribery among Members of Parliament in India. However, it would have to be discussed by the Indian Parliament, before it could implement the necessary amendment to the Prevention of Corruption Act 1988 to provide for the prosecution of Members of Parliament for bribery charges irrespective of whether the alleged offence occurred inside or outside Parliament.

\section{THE 1993 NO-CONFIDENCE MOTION}

On 26 July 1993, a no-confidence motion was moved in Parliament against the minority government of the then Prime Minister of India, Mr P V Narasimha Rao. At that time he had the support of 251 Members of Parliament out of 533. Mr Rao and his party's high command were alleged to have engineered a campaign of bribing and splitting the membership of different political parties in Parliament in order to defeat the no-confidence motion. On 28 July 1993, the no-confidence motion was successfully defeated on the floor.

In 1996, a complaint against the Prime Minister Mr P V Narasimha Rao and others was filed with the Central Bureau of Investigation - India (the CBI) alleging that in 1993 there had been a criminal conspiracy by the ruling party to gain a majority on the floor by bribing Members of Parliament from different political parties, individuals and groups. On the basis of the complaint, cases were registered against $\mathrm{Mr} \mathrm{P} V$ Narasimha Rao and others under s. 120-B of the Indian Penal Code (IPC) and s. 7, 12, 13(2), read with $13(1)(\mathrm{d})(\mathrm{iii})$, of the Prevention of Corruption Act 1988. After the completion of its investigation the CBI filed three charge sheets before a Special Judge. The charges against Mr P V Narasimha Rao by the Special Judge (PVN Rao, p. 705) read as follows:

'That, you, P V Narasimha Rao, between July and August 1993 at Delhi and Bangalore were party to a criminal conspiracy and agreed to enter into an agreement with your coaccused to defeat the no-confidence motion moved on 26-7-1993 against the then Congress Government headed by you by illegal means, viz., to offer or cause to offer and pay gratification other than the legal remuneration to your coaccused persons namely $J M M$ and Janata Dala MPs named above as a motive or reward for their helping in defeating the said no-confidence motion moved by the opposition parties and in pursuance of the said agreement you paid or caused to pay several lakhs of rupees to the above referred JMM and Janata Dala MPs who obtained or attempted to obtain the same in the manner stated above and thereby you have committed an offence punishable under s. 120-B IPC read with s. 7, 12, 13(2) and read with s. $13(1)(d)$ of the Prevention of Corruption Act 1988 within my cognisance.

Secondly, you, P V Narasimha Rao in pursuance of the aforesaid criminal conspiracy during the aforesaid period and at the aforesaid places abetted the commission of the offence punishable under s. 7 of the Prevention of Corruption Act by above referred J M M and Janata Dala MPs and thereby you have committed an offence punishable under s. 12 of the Prevention of Corruption Act and within my cognisance.'

Similar charges were brought against other persons allegedly involved in these acts of bribery.

\section{LEGAL BATTLE FROM TRIAL COURT TO SUPREME COURT}

The accused initially raised objections concerning the jurisdiction of the court to try the case on the ground of the privileges and immunities of the House of Parliament. However, the Special Judge overruled these objections by holding that the case before him did not relate to the pattern of voting in Parliament, but to alleged illegal acts committed by the accused outside Parliament. The 
accused also contended that as they were not public servants, the Prevention of Corruption Act 1988 was not relevant in this case. The Special Judge rejected their objection, citing a Delhi High Court judgment (L K Advani v Central Bureau of Investigation (1997) 66 DLT 618) which held that a Member of Parliament is a public servant.

The Special Judge's order was later challenged before the Delhi High Court, which declined to interfere with the order. Eventually the case reached a Full Bench of the Supreme Court, which, after hearing argument from both sides, felt that the questions raised by the accused should be decided by the Constitutional Bench. Accordingly the Full Bench raised the following substantial question of law:

'as to the interpretation of art. 105 of the Constitution of India raised by the petitioners/accused persons.'

The dissenting judgment of $\mathrm{Mr}$ Justice Agrawal and $\mathrm{Mr}$ Justice Anand (concurring), found that the petitioners were not entitled to claim immunity. On the other hand, the majority opinion of $\mathrm{Mr}$ Justice Bharucha and $\mathrm{Mr}$ Justice Rajendra Babu (concurring) and the separate opinion filed by Mr Justice G N Ray found that bribe takers who voted in the no-confidence motion could not be prosecuted for the alleged crime.

Both majority and dissenting opinion relied mainly on Commonwealth judicial decisions, UK Parliamentary reports and Erskine May's Parliamentary Practice.

\section{POSITION IN THE UK}

Where similar situations have arisen in the UK such as 'cash for questions' involving Members of Parliament, Parliament has commissioned reports to resolve the issues (D Oliver \& G Drewry, eds, The Law and Parliament, Butterworths, 1998). Parliamentary reports such as the Salmon Report on Conduct in Public Life (1976 Cmnd 6524) and the Nolan Committee Report on Standards in Public Life (HMSO: London 1995) were referred to by the Constitutional Bench in detail.

The Salmon Committee (at p. 98) addressed the issue of bribery of Members of Parliament thus:

'... neither the statutory nor the common law applies to the bribery or attempted bribery of a Member of Parliament in respect of his parliamentary activities but "corrupt transactions" involving a Member of Parliament in respect of matters that had nothing to do with his parliamentary activities would be caught by the ordinary criminal law.'

The Salmon Committee recommended (at para. 311, p. 99) that Members of Parliament should be brought within the ambit of the criminal law for corruption, bribery and attempted bribery.

\footnotetext{
'Membership of Parliament is a great honour and carries with it a special duty to maintain the highest standards of probity,
} and this duty has almost invariably been strictly observed ... We recommend that Parliament should consider bringing corruption, bribery and attempted bribery of a Member of Parliament acting in his parliamentary capacity within the ambit of the criminal law.'

Nearly 20 years after the Salmon Report, the 1995 Nolan Committee Report (at para. 104, p. 43) suggested that the issue be left to the Law Commission.

'... We recommend that the Government should now take steps to clarify the law relating to the bribery of or the receipt of a bribe by a Member of Parliament... This might be a task which the Law Commission could take forward.'

In the period between these two reports, Buckley J, in an unreported judgment in 1992 (1998 PL 356 at 363) held:

'That a Member of Parliament against whom there is a prima facie case of corruption should be immune from prosecution in the court of laws is to my mind an unacceptable proposition at the present time. I do not believe it to be the law.'

The recent Joint Committee Report on Parliamentary Privilege discussed Buckley J's decision but noted that it had not been considered by a higher court (at para. 136, p. 40):

‘... The trial judge ruled that members were subject to the common law offence, but his ruling was not tested before the court of appeal.'

Mr Justice Bharucha (party to the majority) expressed a similar opinion to the Joint Committee Report:

'For the first time in England, Buckley $J$ ruled in $R v$ Greenway that the member of parliament who accepts a bribe to abuse his trust is guilty of the common law offence of bribery. This innovation in English law needs to be tested in appeal.' (PVN Rao at p. 731)

It is pertinent to mention here that the report by the UK Joint Committee on Parliamentary Privilege (1999) recommended that Members of Parliament should be liable for prosecution for bribery charges under the criminal law with the consent of the Attorney-General. The relevant portion of the report (p. 5) is reproduced here:

\section{'Bribery}

[Members of either house are at present subject by statute to the law of bribery in respect of proceedings in Parliament]

Recommendation 13. Members of both houses should be included within the scope of forthcoming legislation on corruption. Article 9 (Bill of Rights 1689) should be set aside in any criminal proceedings for bribery. Prosecution under the new legislation, whether of a member or non-member should require the consent of a law officer.'

Further the Report recommended (at para. 173, p. 48):

'...We agree, and recommend that prosecution under the new legislation should require the consent of the Attorney General or, in Scotland, the express consent of the Lord Advocate.' 